\title{
ПСИХОЛОГІЧНИЙ СУПРОВІД ПРОФЕСІЙНОЇ РЕАЛІЗАЦІЇ ФАХІВЦЯ ІНДУСТРІї МОДИ
}

\section{Костюченко О.В.}

\begin{abstract}
Доктор психологічних наук, дочент, професор кафедри індустрії моди, Київський національний університет культури і мистецтвв, Київ (Украӥна)
\end{abstract}

Анотація. У статті означено місие і роль психологічного супроводу у професійній реалізачії фахівия індустрії моди (ФІМ) як рекреаційної изілісної системи, що включає системне та комплексне пробудження $і$ вивільнення здібностей, залучення невикористаних психічних резервів людини щзодо оптимізачії $і$ формування, розширення репертуару актуальних форм творчого самовиявлення, самопрезентаиіï і самоактуалізації. У контексті проблем сфери індустрії моди виокремлено: найзагальніші напрями дослідження психотехнологій; складові у структурі професійності ФІМ; форми цілеспрямованого психолого-педагогічного впливу на його психологічну культуру; психологічні фактори, які визначають ефективну діяльність; психологічні проблеми, щуо потребують застосування психотехнологій; змістовні блоки професійної підготовки.

Ключові слова: психологічний супровід, рекреація, рекреаційні технології, професійна реалізація, індустрія моди, фахівець індустрії моди.

Постановка проблеми. Специфіку психологічних теоретико-прикладних основ у будь-якій сфері, в тому числі й у професійній реалізацій фахівця індустрії моди визначає рекреація (від-творення - re-creatio) як відтворення людини у творчому, культурному, духо- вному, фізичному, психічному (інтелектуальному, емоційному) плані, тобто становлення, розвиток і самореалізація сутнісних сил особистості - прагнення особистості до відтворення себе до рівня ідеального «Яобраза». Наведене послужило предметом аналізу різних галузей науки та розглядається у 
біологічному, медичному, психологічному, соціальному, екологічному аспектах і охоплює величезний спектр проблем, у вирішенні яких беруть участь психологи, педагоги, медики, екологи, культурологи, соціологи, менеджери, мистецтвознавці, дозвіллєзнавці, стилісти, архітектори тощо [3].

Розвиненість моди як соціального феномену (теорія «просочування» - «trickledown» theory, америк. економіст Т. Веблен, нім. соціолог Г. Зіммель) вважають ознакою споживацького суспільства. Але про моду не можна судити лише як про соціальне або психологічне явище, оскільки циклічну зміну форм моди зумовлено об'єктивним розвитком культури. Індустрія моди (fashion industry) як певний сектор економіки, сектор сфери послуг, зайнятий формуванням у покупців образу «модної» продукції, її виробництвом і реалізацією. Продукти діяльності індустрії моди є не лише засобами задоволення естетичних потреб і демонстрації соціального статусу їх власника, але й засобами спілкування між людьми, формою масової комунікації. Наслідування моди виявляє ставлення людини до суспільства, до навколишнього світу, до самої себе. 3 одного боку, особистість хоче зберегти свою індивідуальність, а $з$ іншого - прагне ідентифікувати себе з іншими членами суспільства. Економіка моди зростає швидкими темпами, обганяючи інші галузі економіки. Ця тенденція є сталою та відображає зростання рівня життя і свободи самовираження.

\section{Аналіз останніх досліджень і публіка-}

цій. Здійснений аналіз наукової літератури з проблем професійного становлення та розвитку, професіоналізації фахівця взагалі засвідчує, що дослідженню окремих питань зазначеного предметного простору значну увагу приділяють як вітчизняні науковці (К. Абульханова-Славська, О. Асмолов, О. Гура, Є. Климов, С. Максименко, В. Шадриков та ін.), так і зарубіжні вчені (Е. Гінцберг, Г. Ебінгауз, Г. Мюнстенберг, Ф. Парсонс, Д. Супер та ін.). Різні аспекти досліджуваної проблеми знайшли своє відображення в наукових працях, спрямованих на: визначення сутності професійного розвитку особистості (Б. Ананьєв, Г. БалЛ, Л. Мітіна, М. Пряжников, Н. Чепелєва, Т. Яценко та ін.); визначення концептуальних положень психологічного супроводу як системи професійної діяльності (Р. Бітянова, Н. Глуханюк, Р. Овчарова та ін.). Проте, незважаючи на значний інтерес науковців до питань забезпечення успішності професіогенезу майбутніх фахівців [1;2], проблема психологічного супроводу професійного розвитку майбутнього фахівця індустрії моди (у подальшому ФIM) у ВНЗ як у теоретичному, так і в практичному аспекті залишається майже недослідженою

Мета статті полягає у науковому обгрунтуванні технології психологічного супроводу професійної реалізації фахівця індустрії моди.

Виклад основного матеріалу і резуль- 
татів дослідження. У контексті проблем сфери індустрії моди у структурі прикладної психології можна виокремити два найзагальніші напрями дослідження психотехнологій. Перший - коли психотехнології співвідносять із проблемами професійної діяльності фахівців; у цьому разі проблема застосування психотехнологій тісно пов'язана 3 організацією режимів праці та відпочинку, відновленням розумової працездатності, вибором видів дозвіллєвої діяльності відповідно до характеру й інтенсивності інтелектуальних, фізичних та емоційних навантажень у процесі основної діяльності, а зважаючи на викладене - із психічним і фізичним здоров'ям людини в цілому. Другий напрям пов'язаний з організацією діяльності ФІМ як такого; особливої актуальності зазначений напрям набув у міру розвитку цієї індустрії і розуміння іiі як особливої сфери життя суспільства та особистості. Ідея про інтеграцію рекреаційного, розважального і розвиваючого потенціалів діяльності, пов'язаної зі сферою краси та моди, у процесі її організації актуалізувала проблему пошуків і розробки відповідних психотехнологій.

У нашій редакції категорія рекреаційні психотехнології - комплексна інтегративна система, яка включає впорядковану кількість операцій і дій, що забезпечують рекреаційне цілевизначення, змістовні, інформаційнопредметні й процесуальні аспекти, спрямовані на активізацію когнітивної сфери, відновлення оптимального психічного стану, формування особистісних якостей, підвищення ефективності спілкування та взаємодії, засвоєння знань, напрацювання вмінь, заданих цілями професійної реалізації ФІМ.

Цілеспрямований

психологопедагогічний вплив на особистість ФІМ здійснюється у трьох формах: у виді виховання, систематичного навчання та спеціалізованих тренінгів (системи вправ). Завдяки вихованню формується спрямованість особистості, іiі інтереси, вищі - пізнавальні, моральні та естетичні - потреби, воля, ціннісні орієнтації, культура почуттів. Систематичне навчання дає знання, загальний рівень культури, формує поняття та логічне мислення, розвиває асоціації та уяву, визначає розвиток особистості. За допомогою вправ відбувається тренування окремих навичок та вмінь, психічних процесів, дій і властивостей особистості, пов'язаних із ними. Важливішою метою вправ є формування працездатності, без якої усі надбання особистості та увесь іï досвід виявляються некорисними, втрачають сенс. Важливим завданням $€$ не просто засвоєння знань, навичок і прийомів майстерності, а й розвиток творчого потенціалу, створення для нього найсприятливіших умов, необхідних для самореалізації, застосування засобів стимуляції творчої активності.

У психологічній культурі як турботі про власне психічне здоров'я, вмінні виходити із психологічної кризи самому та допомагати близьким, виокремлюють три основних компоненти: 1) самопізнання та самооцінка; 2) 
пізнання інших людей; 3) вміння керувати власною поведінкою, емоціями, спілкуванням. Багато проблем, пов'язаних із рекреацією, людина здатна вирішити самостійно, використовуючи рекомендації спеціалістів. Однак психолого-педагогічна допомога, заснована на власній психологічній культурі, теоретичних знаннях і практичному досвіді, стосовно організації рекреаційної діяльності може бути більш ефективною.

У сучасній індустрії моди фешн-бізнес перетворився на одну із визначальних сфер життя суспільства, важливий фактор його економічного, політичного, культурного та соціального розвитку. Індустрія моди й управління цією галуззю потребують фахівців зі спеціальною підготовкою, здатних реалізувати поставлені перед нею завдання на рівні сучасних вимог. Підготовка спеціалістів для діяльності індустрії моди в усіх країнах світу здійснюється на основі підходів, продиктованих соціокультурними особливостями кожної країни i специфічними проблемами галузі.

Діяльність ФІМ часто сприймається як суто «технологічна», що вимагає насамперед навичок управлінця або технолога. На теперішній час разом 3 економічною природою дедалі більш виразно виявляється соціокультурна сутність індустрії моди, що усвідомлюється як одна із функціональних сфер культури, iii елемент і засіб, чинник впливу на культуру. Соціально-культурна природа індустрії моди виявляється в тому, що вона вважається соціо- культурною діяльністю, спрямованою на розвиток усіх аспектів, пов'язаних із культурою, та впливає на людину, формуючи у неї навички та уміння спілкування за допомогою візуальних засобів, зокрема певного стилю у зовнішності (зачісці, одязі), поведінці. Найвищою метою індустрії моди є процес відтворення (re -create) всіх учасників у фізичному, психічному, культурному, духовному планах; розвиток особистості, реалізація іï сутнісного потенціалу.

До психологічних факторів, які визначають ефективну діяльність ФІМ, фешнбізнесу належать: - розуміння себе та інших, усвідомлення того, що людям властиві якості, які у певних життєвих ситуаціях сприяють або створюють перешкоди, наприклад, імпульсивність, низький рівень самоконтролю можуть ускладнювати стосунки з іншими, спричиняти стреси і хвороби; • само-вдосконалення, пристосування до змін в оточенні - без саморозвитку людина не відповідає вимогам сучасності, не може самореалізуватися в суспільстві, а керівник певного колективу мусить дбати про професійне зростання, навчання та виховання своїх підлеглих; • оптимізація психічних процесів і станів, застосування рекреаційних засобів та методів, що впливають на психологічне, фізичне і соціальне здоров'я та працездатність; - стимулювання та реалізація творчого потенціалу особистості; • підвищення ефективності власної професійної діяльності, якомога повніше використання особистісного поте- 
нціалу людини, налагодження стосунків між членами трудового колективу, психологічне забезпечення діяльності, що передбачає вирішення проблем професійного самовизначення, професійної підготовки і підвищення кваліфікації; • пошук та активізація резервів персоналу; • оцінка та поліпшення соціальнопсихологічного клімату, у тому числі вдосконалення стилю та культури ділових стосунків; • розвиток соціально-психологічної компетентності [4].

Отже, реалізація прикладних аспектів психології у професійній діяльності ФІМ включає різні аспекти дослідження, що стосуються відновлення фізичної та інтелектуальної працездатності фахівця, його виходу зі стресового стану, зумовленого порушенням природного ритму життя в сучасному урбанізованому і техногенному суспільстві, яке поширюється на роботу, навчання, побут. У медичному і психологічному аспектах індивідуальні можливості працездатності організму ми називаємо оптимальним режимом функціонування, який встановлює певні нормативні значення, співвіднесеність рекреації з різними видами діяльності та необхідністю врахування в процесі організації цілого комплексу чинників, пов'язаних з активізацією одних i «відпочинком» інших функціональних систем організму.

Рекреаційну складову професійної самореалізації представлено у контексті таких напрямів медицини і психології: психогігієна (стосовно праці, навчання, розумової діяльності), мистецтвотерапія (музикорекреація, хореотерапія, бібліотерапія, кольоротерапія), природотерапія (фітотерапія, таласотерапія, кристалотерапія, ароматерапія). Слід звернути увагу, що різноманітні терапії (як напрями медицини, психіатрії і психотерапії) орієнтовані на лікування і здійснюються фахівцями відповідних галузей. На відміну від терапії, рекреалогія має своїм завданням оптимізацію природного режиму життя людини в соціальному, культурному, економічному, політичному аспектах, що визначає їі (людини) самопочуття і працездатність. Щоправда, у медицині та психології термін «терапія» останнім часом отримав розширене тлумачення і охоплює виховання, методики сприяння особистісному росту, формування медичної і психологічної культури тощо. Усе це виводить природо- і мистецтвотерапію за межі розуміння їх лише як лікувальних засобів. 3 одного боку, це ще раз засвідчує необхідність міждисциплінарного підходу до рекреаційної проблематики у зазначеному вище розумінні, а 3 іншого - потребує суттєвого уточнення наведеної термінології та встановлення меж іiі застосування у різних науках [4].

Звідси зрозуміло, що психологічний супровід діяльності ФІМ не зводиться до суто психологічних практик нормалізації психічних станів індивіда або розвитку психічних процесів. Він передбачає психологічний аналіз індустрії краси як складного соціокульту- 
рного феномена на рівні взаємин «людиналюдина», «людина-суспільство», «людинакультура», «людина-природа». У цих взаєминах найбільш повно розкривається зв'язок між психофізіологічними,

культурнопсихологічними, культурно-педагогічними, соціально-психологічними, культурноантропологічними тощо напрямами досліджень. Проблема здоров'я у фізичних, психічних, соціальних, культурних відносинах також постає у рекреаційному вимірі як соціокультурна, що припускає осмислення зазначених відносин людини.

Цілеспрямована активність ФІМ у соціокультурному плані - це ніщо інше, як творча діяльність. Тому під час розгляду різних психолого-педагогічних напрямів дослідження рекреаційних можливостей індустрії моди у межах соціокультурного підходу значну увагу приділяють саме процесам творчості й розкриття творчого потенціалу особистості як найважливішої умови іiї самореалізації.

Отже, до основних психологічних проблем ФІМ у нашому практично-орієнтованому викладі, тобто показань до застосування психотехнологій, належать такі:

Внутрішнього порядку, що пов'язані 3 особливостями особистості ФІМ і споживача продуктів його діяльності: • невпевненість у власних силах (сумніви, негативні очікування, внутрішні суперечності), низький ступінь самосприйняття - головний фактор обмеження, який заважає розпочати дійсно значну справу, зробити перший крок, довести свої починання до переможного фіналу. Внутрішні суперечності, посилюючись, часто призводять до справжнього внутрішнього конфлікту: одна частина особистості, зігнувшись від утоми, тягне на собі цілу купу турбот і рутини, але рухається вперед за міражем успіху, натомість інша активно їй протидіє, не гребуючи жодними засобами, від саботажу до диверсії, спрямованих... на власний організм; • невміння «подати» себе у спілкуванні; - труднощі емоційного розвитку, зайва емоційність, психоемоційна напруга, що призводять до бурхливих сплесків емоцій, іноді з драматичними наслідками; • повторюваність травматичних спогадів про пережиті стреси, актуальний стрес; зниження емоційного тонусу; імпульсивність емоційних реакцій, що отруюють життя та погіршують самопочуття, - посттравматичні стресові розлади; • тривожність, панічні атаки, нав'язливі думки та страхи, неможливість опанувати себе; • безпричинне, невмотивоване зниження працездатності, що супроводжується зниженням загального тонусу (астенічні стани і синдром хронічної втоми); • психологічна складова багатьох проблем зі здоров'ям, зумовлених стресом (психосоматичних захворювань); • постійно пригнічений настрій; відсутність зацікавленості, байдужність до навколишнього світу; втрата інтересу до життя, іншими словами - депресія (iї причиною часто $€$ назрівання конфлікту між свідомістю та підсвідомістю), найчастіше - лише негативні ду- 
мки, які можна відкинути, як і всі інші, що заважають самореалізації людини.

Зовнішнього порядку, зумовлені: • спілкуванням та взаємодією із соціумом. Розвиток ринкових відносин у нашій країні дав змогу сформуватися широкому колу підприємців, діяльність яких пов'язана з індустрією моди. У цих видах бізнесу багато залежить від уміння працювати 3 клієнтами, від широкого світогляду, знань гуманітарного, психологічного, художнього плану, від культури обслуговування в цілому. До того ж через посилення конкуренції у сфері бізнесу підвищуються вимоги до іміджу фірми та репутації бізнесмена, до корпоративної культури і професійного етикету. Ігнорування цих аспектів підприємницької активності обертається крахом фірми, матеріальними та моральними втратами. Ще одна важлива особливість сучасного українського підприємництва у фешн-сфері полягає у тому, що його представники постійно перебувають у сфері міжкультурних комунікацій. Для успіху їх професійної діяльності важливими $є$ знання і розуміння ділових культур різних країн, врахування національної психології, традицій, звичаїв партнерів і клієнтів із різних регіонів світу; - потребою розпочати комунікацію та ефективно спілкуватися з іншими людьми; реалізації творчого потенціалу у продуктах професійної діяльності; дослідження та формування образу світу тощо; • умовами діяльності, рівнем комфорту як якісної характеристики душевного стану людини, що пов'язаний з її внутрішнім спокоєм, відсутністю конфлікту із собою та зовнішнім світом; сукупність зручностей. Важливим є забезпечення різних видів комфорту, а саме: 1) побутового (впорядковування, безпека, затишок, створення нормальних умов для споживача послуг); 2) інформаційного (своєчасне повідомлення необхідної інформації про умови проведення заходів, про засоби та продукти діяльності; інформованість персоналу, готового надати будь-яку інформацію, що цікавить споживачів продуктів діяльності фешнбізнесу; система піктограм, яка має допомогти замовнику зорієнтуватися у професійному оточенні, не володіючи мовою країни перебування); 3) психологічного (сприятливий психологічний клімат, створений персоналом у процесі професійної діяльності 3 метою нормалізації психологічного стану споживача продуктів діяльності); 4) економічного (зручність розрахунків, наявність системи дисконту, бонусів, клубних карт тощо; заходи, спрямовані на мотивування повторного вибору певної фірми, фешн-компанії); 4) естетичного (атмосфера затишку, створена під час перебування у закладах фешн-бізнесу - якого можна досягти завдяки кольоровій гаммі, стильовому дизайну приміщень, а також використанню в інтер'єрі матеріалів, що відповідають вимогам безпеки і гігієни).

У контексті наведеного вбачається за доцільне розмежувати загальний і варіативний компоненти змісту підготовки ФІМ. Пер- 
ший відображає загальні функції діяльності та задачі фахівця; другий - особливості, продиктовані актуальною соціально-культурною ситуацією з урахуванням змін, що відбуваються (наприклад, зміна попиту на ті чи інші послуги, зміни у нормативно-правовій базі, освітніх, управлінських технологіях тощо). Варіативний компонент виконує адаптивну функцію системи підготовки фахівців.

При підготовці ФІМ у контексті основних функцій моди (комунікативної, інтеракційної, компенсаторної, розвиваючої, рекреаційної і розважальної) доцільно орієнтуватися на такі змістовні блоки. 1. Психологопедагогічний супровід IM зумовлений суспільною необхідністю соціалізації та інкультурації особистості. Слід наголосити, що в Україні психологічний супровід фешн-бізнесу наразі практично відсутній, тому він вважається одним із напрямів культурної політики в індустрії моди і підготовці фахівця. ФІМ мають бути здатними надавати освітньорекреаційні послуги із застосуванням новітніх технологій та сучасних технологічних досягнень, залучати людей (особливо молодь і підлітків) до моди як мистецтва та культурної цінності, до модотворчості, формуючи екологічну, естетичну, інформаційну, фізичну, правову і т.і. культуру; створювати засоби, що не виходять за межі здорового способу життя. 2. Реалізація рекреаційно-розважальної функції сфери краси та моди відображає актуальну потребу в організації відпочинку і розваг, від- новленні фізичних, психічних, інтелектуальних сил людини під час beauty-fashionзаходів. Тому ФІМ мають володіти знаннями та уміннями в галузі режисури, сценарної майстерності, сценографії, організації і проведення шоу-програм. 3. Розробка і реалізація соціально-культурних дозвіллєвих програм передбачає здатність ФІМ проектувати і впроваджувати комплексні лонгітюдні програми, в тому числі регіональні, для різних груп населення. У сучасному суспільстві постала нагальна потреба у реалізації єдиної продуманої соціально-культурної політики в індустрії краси та моди. Такі програми є багатоцільовими і передбачають інтеграцію діяльності різних соціальних інститутів. 4. Керівництво діяльністю установ індустрії моди базується на знанні специфіки та володінні технологіями проектування, планування й організації фешндіяльності, фахівець такого профілю може розробляти і впроваджувати відповідні програми діяльності установ індустрії моди. На сьогодні фахівець із фешн-технологій (маючи відповідну підготовку з менеджменту, маркетингу, іміджелогії, управління персоналом, психології) також здатний здійснювати керівні функції в установах. Отже, цей змістовний блок підготовки фахівця вважається суттєвим. У межах такого блоку передбачено (крім названих вище) знання і уміння, що дають фахівцю змогу здійснювати організаційнометодичні та адміністративно-господарські функції установ IM; надавати методичну до- 
помогу персоналу, зайнятому у сфері послуг індустрії моди, а також виконувати функції систематизації, поширення і впровадження інновацій у діяльність зазначених установ.

Такий фахівець повинен володіти комплексом професійно-особистісних якостей, що дають йому можливість здійснювати ціннісноорієнтаційну, комунікативно-організаторську, інформаційно-освітню, творчо-конструктивну, рекреативно-розважальну, пошуководослідницьку функції.

Висновки. Отже, швидкоплинність соціального прогресу, динамічні зміни суспільства в усіх сферах, зокрема індустрії моди, зумовлюють необхідність професійної реалізації особистості, важливість феномена якої має прояв не тільки у процесі поступального особистісного й професійного розвитку, самовдосконалення, досягнення гармонії, але й відіграє важливу роль в усіх інших формах реалізації особистості - соціальній, особистісній та ін.. Психологічний супровід професійної реалізації фахівця індустрії моди за своїм змістом являє собою цілісну систему, що включає системне та комплексне пробудження i вивільнення здібностей, залучення невикористаних психічних резервів людини щодо оптимізації і формування, розширення репертуару актуальних форм творчого самовиявлення, самопрезентації і самоактуалізації.

\section{Перспективи подальших досліджень.} Перспективним у цьому зв'язку є соціокультурний та міжкультурний, гендерний, віковий порівняльний аналіз особливостей (факторів, засобів, стратегій і тактик, характеристик); додаткової уваги потребує дослідження умов сприятливого середовища, в якому відбувається формування позитивного, багатогранного «Я-образу», що сприяє професійному здійсненню і вдосконаленню.

\section{Перелік використаних джерел:}

1. Корень T.О. Сучасні напрями психологізації професійної підготовки фахівців : монографія: у 4 т. / В.Й. Бочелюк, С.А. Білоусов, Т.О. Корень та інші ; [за ред. В.Й. Бочелюка]. - Запоріжжя : КПУ, 2010. - Т. 1. 348 c. - С. $245-251$.

2. Коростылева Л.А. Самореализация личност и в профессиональной сфере: генезис затруднений / Л.А. Коростылева ; под ред. Г.С. Никифорова, Л.А. Коростылевой. - СПб. : Изд-во С.-Петербургского университета, 2001. - С. 3-23.

3. Костюченко О.В. Основні напрями психологічного дослідження адаптації та рекреації у контексті психічного здоров'я / О.В. Костюченко // Актуальні проблеми психології: Збірник наукових праць / за ред.. В.О. Моляко. - Т.12. - Вип.10. - Житомир: Вид-во ЖДУ ім. І Франка, 2010. - 460c. - С. 154-161.

4. Костюченко О.В. Психологія ефект ивност і фахівця індустрії моди: Навчально-методичний посібник. / О.В. Костюченко, Л.П. Дихнич. - Київ.: Ліра-К, 2016. $464 \mathrm{c}$.

\section{References (Transliteration):}

1. Koren T.O. SuchasnI napryami psihologIzatsIYi profesIynoYi pIdgotovki fahIvtsIv : monografIya: u 4 t. / V.Y. Bochelyuk, S.A. BIlousov, T.O. Koren ta InshI ; [za red. V.Y. Bochelyuka]. - ZaporIzhzhya : KPU, 2010. - T. 1. - 
348 s. - S. 245-251.

2. Korostyileva L.A. Samorealizatsiya lichnosti v professionalnoy sfere: genezis zatrudneniy / L.A. Korostyileva ; pod red. G.S. Nikiforova, L.A. Korostyilevoy. - SPb. : Izd-vo S.-Peterburgskogo universiteta, 2001. - S. 3-23.

3. Kostyuchenko O.V. OsnovnI napryami psihologIchnogo dosIIdzhennya adaptatsIYi ta rekreatsIYi u kontekstI psihIchnogo zdorov'ya / O.V. Kostyuchenko // AktualnI problemi psihologIYi: ZbIrnik naukovih prats / za red.. V.O. Molyako. - T.12. - Vip.10. - Zhitomir: Vid-vo ZhDU Im. I Franka, 2010. - 460s. - S. 154-161.

4. Kostyuchenko O.V. PsihologIya efektivnostI fahIvtsya IndustrIYi modi: Navchalno-metodichniy posIbnik. / O.V. Kostyuchenko, L.P. Dihnich

\section{Kostyuchenko Olena}

Doctor of psychological Sciences, associate Professor, Professor of the fashion industry, Kyiv national University of culture and arts, Kiev (Ukraine).

\section{PSYCHOLOGICAL SUPPORT OF PROFESSIONAL SPECIALIST OF FASHION INDUSTRY}

\section{ABSTRACT}

The article examines the recreational nature of professional realization as one of the important factors of personality as human reproduction in the creative, cultural, spiritual, physical, mental (intellectual, emotional) terms; as a holistic and integral implementation of creative and adaptive capacities, based on what are the problems of adaptation to changing environmental conditions, growth, development, human self. Appointed place and role of psychological support professional fulfillment specialist fashion industry (SIM). In the context of the scope of the fashion industry in the structure of applied psychology singled out the two most common areas of research Psy-related problems of professional experts and the organization of SIM itself, orientation on integrate recreational, entertainment and developmental potential activities related to the field of beauty and fashion. The essence recreational Psy as a complex integrative system that includes an ordered number of transactions and activities that provide recreational aimdetermination, content, information and substantive and procedural aspects aimed at enhancing cognitive, restoration of optimal mental state, the formation of personal qualities, effective communication and interaction, learning, skills developments, given the objectives of professional realization SIM. Special attention is focused: on the components of the structure SIM professionalism; focused on forms of psychological and educational impact on his psychological culture; psychological factors that determine the effective activities; on the psychological problems that require the use Psy; on content units training in the context of the main functions of fashion. Indicated that psychological support professional realization SIM its content is a holistic system that includes systematic and comprehensive awakening and liberation of abilities, involvement untapped reserves of mental Rights on optimizing and forming, expanding the repertoire of current forms of creative self-expression, and self- 
actualization.

Keywords: psychological support, recreation, recreational technology, professional sales, fashion industry, fashion industry expert.

\section{Костюченко Елена Викторовна}

Доктор психологических наук, дочент, профессор кафедры индустрии моды, Киевский наџиональньий университет культуры и искусств, Киев (Украина)

\section{ПСИХОЛОГИЧЕСКОЕ СОПРОВОЖДЕНИЕ ПРОФЕССИОНАЛЬ- НОЙ РЕАЛИЗАЦИИ СПЕЦИАЛИСТА ИНДУСТРИИ МОДЫ}

Аннотация. В статье определены место и роль психологического сопровождения в профессиональной реализации специалиста индустрии моды как рекреационной целостной системы, включающий системное и комплексное пробуждение и высвобождение способностей, привлечения неиспользованных психических резервов человека в оптимизации и формировании, расширении репертуара актуальных форм творческого самовыражения, самопрезентации и самоактуализации. В контексте проблем сферы индустрии моды выделены: самые общие направления исследования психотехнологий; составляющие в структуре профессионализма специалиста индустрии моды; формы целенаправленного психолого-педагогического воздействия на его психологическую культуру; психологические факторы, определяющие эффективную деятельность; психологические проблемы, требующие применения психотехнологий; содержательные блоки профессиональной подготовки.

Ключевые слова: психологическое сопровождение, рекреация, рекреационные технологии, профессиональная реализация, индустрия моды, специалист индустрии моды. 